\title{
Light responses of the planktotrophic larva of the serpulid polychaete Spirobranchus polycerus
}

\author{
J. R. Marsden \\ Department of Biology, McGill University, 1205 Ave. Dr. Penfield, Montreal, Quebec, Canada H3A 1B1 \\ and \\ The Bellairs Research Institute of McGill University, St. James, Barbados, West Indies
}

\begin{abstract}
Planktotrophic larvae of the tropical, gregarious serpulid Spirobranchus polycerus (Schmarda) were photonegative or photoneutral at age 16 to $22 \mathrm{~h}$ and photopositive or photoneutral at 72 to $350 \mathrm{~h}$ in response to a horizontal beam of white light. During the 22 to $72 \mathrm{~h}$ interval larvae may be photonegative, photoneutral or photopositive. They were indifferent to wavelengths longer than $590 \mathrm{~nm}$. Larval age, level of irradiance and duration of exposure all influence the strength of the photopositive response. Orientation of the eyespot and adaptation of light-sensitive elements were discussed as factors influencing the strength of the photopositive response. The varied light responses of planktotrophic serpulid larvae could have resulted from natural selection in the plankton community. The role of these behaviours in relation to the distribution of larvae in the sea is unknown.
\end{abstract}

\section{INTRODUCTION}

The single 2-celled eyespot is a characteristic feature of the trochophore and early metatrochophore larva of serpulid polychaetes. A photoresponse has been quantified for larvae of 3 species, Serpula vermicularis from the Pacific coast of North America (Young \& Chia 1982), Spirobranchus giganteus from the Caribbean (Marsden 1984, 1986) and the Australian Galeolaria caespitosa (Marsden 1988). The sign, strength and consistency of the response varies between these species. The larva of $S$, giganteus is initially photopositive and becomes photoneutral as a late metatrochophore. The $G$. caespitosa larva is initially photonegative, becoming photopositive at the late metatrochophore stage, and $S$ vermicularis trochophores are briefly photopositive, habituating to become photonegative. These differences in behaviour suggest different patterns of distribution in the sea.

Mathematical modelling of the distribution of planktonic organisms together with studies on the distribution of planktonic larvae in estuaries and controlled laboratory experiments on larval behaviour (Mackas et al. 1985, Jackson 1986, Stancyk \& Feller 1986, Richards \& Lindeman 1987) support the view that the distribution of large larval forms (fish, decapods) is achieved by a combination of passive physical transport and species-specific patterns of larval behaviour. The case for the smaller larvae of cirripedes, lamellibranchs, polychaetes and echinoderms is not clear. Distribution studies on larvae of cirripedes (Bousfield 1955, de Wolf 1973, 1974, Grosberg 1982), oysters (Carriker 1947, Nelson 1955, Kunkle 1957, Wood \& Hargis 1971) and polychaetes and echinoderms (Lyster 1965, Banse 1986, Levin 1986) give rise to conflicting opinions on the role of larval behaviour in distribution. Examples of good correlations between behaviours observed in the laboratory and the distribution of larvae in the field (Cronin \& Forward 1986, Yoshioka 1986) are rare. In this situation more information is needed in both areas (Stancyk \& Feller 1986). The following study documents laboratory-observed behaviour of the larva of Spirobranchus polycerus and provides further evidence for species-specific responses to light by planktotrophic serpulid larvae.

\section{MATERIALS AND METHODS}

Larval rearing. Spirobranchus polycerus was collected at low tide at Martin's Bay on the east coast of Barbados between May and July 1987 and between January and June 1988 and 1989. Small aggregations of tubes were chipped off intertidal rocks and brought into the laboratory where worms were removed from tubes and ripe individuals collected in fingerbowls. 
Spawning occurred within 10 to $15 \mathrm{~min}$. Ova from 5 or 6 females were fertilized with spermatozoa from an equivalent number of males. Larval cultures were kept in bowls set in running seawater at 26 to $29^{\circ} \mathrm{C}$. Cultures were fed Isochrysis galbana ( $\mathrm{T}$ strain) daily. Culture water was changed every second day.

Testing procedure. Larvae were tested in a rectangular $(70 \times 10 \times 6 \mathrm{~mm})$ plastic chamber set on a strip of black velvet on the stage of a Zeiss dissecting microscope. The sides and one end of the chamber were opaque and a coverglass affixed to the other end provided a window for the entry of a horizontal beam of light. The size of the beam was restricted by a cardboard mask. Larvae were counted in three $6 \mathrm{~mm}$ wide corridors across the chamber. Corridor A occupied the window end of the chamber; B was located 27 to $33 \mathrm{~mm}$ from the window and $C$ was at the back of the chamber, 64 to $70 \mathrm{~mm}$ from the window. A larval culture was dark-adapted for $1 \mathrm{~h}$; then, under red light (a red filter used with white light at $360 \times 10^{14}$ quanta $\mathrm{cm}^{-2} \mathrm{~s}^{-1}$ ), a $3 \mathrm{ml}$ sample was removed from the culture and expelled into the centre of the chamber, already in position on the microscope stage. The chamber was left undisturbed in the dark for $15 \mathrm{~min}$ before starting an experiment. The number of Iarvae in the chamber experiment varied with the density of the larval culture used. Estimated numbers per chamber were 100 to 400 for actively swimming larvae and 30 to 50 for demersal 3 -setiger stages. The number of larvae counted in any one corridor varied from 120 to 0 . All tests were carried out in a darkened room at 25 to $26^{\circ} \mathrm{C}$ between $10: 00$ and 14:00 h. Each experiment consisted of 3 counts made 5, 10 and $15 \mathrm{~min}$ after the light was turned on. The light source was a Dolan-Jenner fibre optics lamp fitted with a Zeiss conversion filter $(5600 \mathrm{~K})$. The irradiance level was changed by varying the distance between lamp and window. Irradiance levels were calibrated in seawater using an integrating quantum scalar irradiance meter (DSI-140, Biospherical Instruments Inc.) with an equal quantum response to light in the 400 to $700 \mathrm{~nm}$ range. Four levels of irradiance were used: $147,360,1045$ and $2000 \times 10^{14} \mathrm{q} \mathrm{cm}^{-2} \mathrm{~s}^{-1}$. These levels fall within the range $\left(35\right.$ to $2599 \times 10^{14} \mathrm{G} \mathrm{cm}^{-2}$ $\mathrm{s}^{-1}$ ) of photosynthetically active radiation measured in 1987 at depths between 1 and $4 \mathrm{~m}$ on 8 Barbados reefs (T. Tomascik pers. comm.) and are, consequently, levels that larvae in waters around Barbados might be expected to encounter. Larvae were considered to show a photoresponse when their distribution between the 3 corridors was statistically uneven as a result of higher numbers at $A$ or $C$. A significantly higher number of larvae at $\mathrm{A}$ than at $\mathrm{B}$ or $\mathrm{C}$ was regarded as a photopositive response. A significantly higher number at $\mathrm{C}$ than at $\mathrm{A}$ or $\mathrm{B}$ was regarded as a photonegative response. Any other distribution was regarded as a photoneutral response. The strength of the photopositive or photonegative response was expressed as the percent of the total number of larvae counted that were found at $\mathrm{A}$ or $\mathrm{C}$. Non-parametric methods were used in statistical analysis since the data, even when transformed, did not meet the requirements of normality and homoscedasticity required for parametric analysis.

Preliminary experiments. Nine preliminary experiments assessing the acceptability of the use of red light, while placing larvae in the chamber and when adding formalin during dark counts, were carried out on 3 to $4 \mathrm{~d}$ larvae using light at an irradiance level of $360 \times 10^{14}$ $\mathrm{q} \mathrm{cm}^{-2} \mathrm{~s}^{-1}$ passed through a Kodak Wratten filter \# 25 (590 $\mathrm{nm}$ and above). The distribution of larvae between the 3 corridors was assessed using a Kruskal-Wallis 1way ANOVA on ranked data (the number of larvae at A, B and C) (Zar 1984).

Dark counts were made by placing a $2 \mathrm{ml}$ sample of larvae in the experimental chamber on the microscope stage illuminated by red light at the irradiance level tested above. After $15 \mathrm{~min}$ in the dark the red light was turned on again and larvae were killed by adding 5 drops of $10 \%$ formalin in seawater at roughly equal intervals along the chamber (tests reported earlier [Marsden 1986] indicated that the drops do not significantly alter the distribution of larvae). The red filter on the microscope lamp was then removed and the number of larvae/corridor counted without moving the chamber. Fifteen dark counts were made, 5 on each of 1 to $2 \mathrm{~d}, 3$ to $4 \mathrm{~d}$ and 5 to $6 \mathrm{~d}$ larvae. The distribution of larvae between the 3 corridors was assessed using a Kruskal-Wallis 1-way ANOVA on ranked data (Zar 1984).

Experiments in Sets 1 and 2. The remaining data come from 2 sets of experiments. The first (Set 1), carried out in 1987 and 1988, used 5 larval cultures and tested larvae at 3 developmental stages: as trochophores ( 1 to $2 \mathrm{~d}$, or between 24 and $31 \mathrm{~h}$ ), as early metatrochophores ( 3 to $4 \mathrm{~d}$ or between 72 and $110 \mathrm{~h}$ ) and as late metatrochophores ( 5 to $6 \mathrm{~d}$ or between 120 and $144 \mathrm{~h}$ ). Fifteen experiments were carried out on each developmental stage at each of the 4 selected levels of irradiance. Each experiment ran for $15 \mathrm{~min}$ and the number of larvae/corridor was counted at 5, 10 and 15 min of exposure. The number of larvae/corridor for each group of experiments, i.e. experiments on one age class at one level of irradiance, were analysed for a difference between corridors, using Friedman's test, a 2-way ANOVA of ranked, randomized block data (Zar 1984). This test was selected because of differences between larval cultures, most obviously differences in larval density. Differences between experiments, i.e. between cultures, were considered to constitute the random variable. The fixed variable was the position of the corridor in the chamber $(A, B$ or $C$ ). When Fried- 
man's test showed a significantly uneven distribution, numbers of larvae at $A, B$ and $C$ were compared in pairs using Tukey's Multiple Comparisons test on ranked data in order to determine if there was a photoresponse and if so, its sign.

The photobehaviour of larvae in individual experiments (Sets 1 and 2) was assessed using the log-likelihood G-statistic test (Zar 1984) on the number of larvae counted in each of the 3 corridors after 15 min exposure to light. When the distribution across corridors was even the response was considered to be photoneutral. When the distribution was uneven, paired G-statistic tests were run to determine if there was a significantly higher number of larvae at $A$ (a photopositive response), B (a photoneutral response) or C (a photonegative response).

The second set of experiments (Set 2), carried out in 1989, used 7 larval cultures and tested larvae over the full developmental range, from early trochophores $(12 \mathrm{~h})$ to 3 -setiger larvae ready to settle (14 d). This set consisted of 135 experiments all conducted at an irradiance level of $1045 \times 10^{14} \mathrm{q} \mathrm{cm}^{-2} \mathrm{~s}^{-1}$. Counts were made after 15 min exposure. The result of each experiment was assessed using the log-likelihood G-statistic.

Strength of photopositive response. The effect of larval age ( 1 to 2,3 to 4 , and 5 to $6 \mathrm{~d}$ ) on the strength of the photopositive response was assessed using a Kruskal-Wallis model 1, 1-way ANOVA (Zar 1984) of the percent of larvae at $A$, after 15 min exposure to light, in all experiments in Set 1 . The effects of duration of exposure $(5,10$ and $15 \mathrm{~min})$ and of level of irradiance (147, 360, 1045 and $2000 \times 10^{14} \mathrm{q} \mathrm{cm}^{-2} \mathrm{~s}^{-1}$ ) on the strength of the photopositive response were assessed using a Kruskal Wallis model 12 -way ANOVA (Zar 1984) of the percent of larvae at A in all experiments in Set 1.

Fig. 1. Spirobranchus polycerus. Set 1 experiments. Mean number of larvae counted in Corridors $\mathrm{A}, \mathrm{B}$ and $\mathrm{C}$ for 15 experiments after 15 min exposure at each of 4 levels of irradiance. (4) $147 \times 10^{14} \mathrm{q}$ $\mathrm{cm}^{-2} \mathrm{~s}^{-1} ;$ (ه) $360 \times 10^{14} \mathrm{q} \mathrm{cm}^{-2} \mathrm{~s}^{-1} ;(\bullet)$ $1045 \times 10^{14} \mathrm{q} \mathrm{cm}^{-2} \mathrm{~s}^{-1}$; (o) $2000 \times 10^{14} \mathrm{q}$ $\mathrm{cm}^{-2} \mathrm{~s}^{-1}$

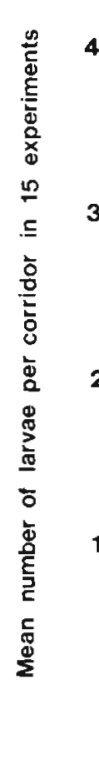

Red light. Larvae under light at $590 \mathrm{~nm}$ and above were evenly distributed between the 3 corridors (Kruskal-Wallis test; $p>0.05$ ), indicating no response to this spectral segment of white light at an irradiance level of $360 \times 10^{14} \mathrm{q} \mathrm{cm}^{-2} \mathrm{~s}^{-1}$.

Dark counts. The distribution of larvae between the 3 corridors after $15 \mathrm{~min}$ in the dark (killed and examined under red light) was uniform for 1 to 2,3 to 4 , and 5 to $6 \mathrm{~d}$ larvae (Kruskal-Wallis test; $\mathrm{p}>0.9$ in all cases), indicating that 1 to $6 \mathrm{~d}$ larvae tend to be evenly distributed in the absence of light at wavelengths below $590 \mathrm{~nm}$.

\section{Set 1 experiments}

Evidence for a photoresponse. Mean values of counts of numbers of larvae/corridor, after $15 \mathrm{~min}$ exposure, for experiments testing the effects of level of irradiance in all 3 age classes are shown in Fig. 1. Each symbol represents a mean of 15 values that varied with the density of the larval culture.

Larvae in all 3 age classes were unevenly distributed across the 3 corridors at all 4 levels of irradiance (Friedman's test; $p<0.05$ in all cases; Table $1 \mathrm{a}, \mathrm{b}$ and $\mathrm{c}$ ). The uneven distribution was in no case due to a concentration of larvae at B. Larvae in all age classes showed a photoresponse at each of the 4 selected levels of irradiance.

Sign of photoresponse. Compilation of the log-likelihood G-statistics for single experiments on 1 to 2,3 to 4 , and 5 to $6 \mathrm{~d}$ larvae shows that an individual experiment may represent a photopositive $(A>B, A>C)$, photonegative $(C>A, C>B)$, or photoneutral response 
(Table 2). The most consistent response pattern was shown by 3 to $4 \mathrm{~d}$ larvae which were most frequently photopositive, less frequently photoneutral and never photonegative. The behaviour of 5 to $6 \mathrm{~d}$ larvae was similar with a rare (2 out of 60 experiments) photonegative response. (Note that in all cases of repeated Gstatistic tests [using $p<0.05$ ] it is likely that 3 out of every 60 evaluations will be wrong.) The results of experiments on 1 to $2 \mathrm{~d}$ larvae were most frequently photoneutral, less frequently photopositive and photonegative in 11 out of 60 cases.

When all experiments on one age class at one level of irradiance are considered together (Friedman's test: Table 1), the uneven distribution of 3 to 4 and 5 to $6 \mathrm{~d}$ larvae is always the consequence of a higher number of larvae at $A$ than at $B$ or $C$ (Tukey's test: $A>B, A>C$; Table $1 b, c)$, indicating an overall photopositive response. The situation for 1 to $2 \mathrm{~d}$ larvae is more complex. At $360 \times 10^{14} \mathrm{q} \mathrm{cm}^{-2} \mathrm{~s}^{-1}$ the number of larvae at $A$ was greater than the number at $B$ or $C$, indicating an overall photopositive response (Table 1a). At the 3 other irradiance levels the number of larvae at $A$ equaled the number at $C$, both values being larger than the number at $B(A=C, A>B, C>B)$, i.e, the experiments show a bimodal distribution, suggesting the presence of both photopositive and photonegative individuals. Examination of G-statistic tests on 1 to $2 \mathrm{~d}$ larvae show the same distribution $(A=C, A>B, C>B)$

Table 1. Spirobranchus polycerus. Analysis of variance (Friedman's test: $\chi^{2}$ and $p$ values) of the number of larvae/corridor at 4 levels of irradiance, followed where appropriate by Tukey's multiple comparisons (q and p values). Fixed variable $=$ position of corridor in chamber. Random variable $=$ experiment number

\begin{tabular}{|c|c|c|c|c|c|c|c|c|}
\hline \multirow{2}{*}{ a. 1 to 2 d larvae } & \multicolumn{8}{|c|}{ Level of irradiance $\left(\times 10^{1 / 4} \mathrm{q} \mathrm{cm}^{-2} \mathrm{~s}^{-1}\right)$} \\
\hline & \multicolumn{2}{|c|}{147} & \multicolumn{2}{|c|}{360} & \multicolumn{2}{|c|}{1045} & \multicolumn{2}{|c|}{2000} \\
\hline \multirow[t]{2}{*}{ Friedman's test } & $x^{2}$ & $\mathrm{p}$ & $x^{2}$ & $\mathrm{p}$ & $x^{2}$ & $\mathrm{p}$ & $\chi^{2}$ & $p$ \\
\hline & 12.43 & $<0.005$ & 30.48 & $<0.001$ & 64.82 & $<0.001$ & 7.23 & $<0.05$ \\
\hline Tukey's test & q & $\mathrm{p}$ & q & $\mathrm{p}$ & q & $p$ & q & p \\
\hline \multirow[t]{2}{*}{$\mathrm{A} / \mathrm{B}$} & 4.91 & $<0.005$ & \multirow{2}{*}{\multicolumn{2}{|c|}{$\begin{aligned} & 4.26<0.01 \\
& A>B\end{aligned}$}} & 4.52 & $<005$ & 2.23 & $<0.1$ \\
\hline & \multicolumn{2}{|c|}{$A>B$} & & & \multicolumn{2}{|c|}{$A>B$} & \multicolumn{2}{|c|}{$A>B$} \\
\hline \multirow[t]{2}{*}{$\mathrm{A} / \mathrm{C}$} & & $<0.05$ & 3.62 & $<0.05$ & \multirow{2}{*}{\multicolumn{2}{|c|}{$\begin{aligned} 0.65 & >0.1 \\
A & =C\end{aligned}$}} & 0.13 & $>0.1$ \\
\hline & \multicolumn{2}{|c|}{$\mathrm{A}=\mathrm{C}$} & \multicolumn{2}{|c|}{$A>C$} & & & \multicolumn{2}{|c|}{$A=C$} \\
\hline \multirow[t]{2}{*}{$\mathrm{B} / \mathrm{C}$} & 3.23 & $>0.1$ & 0.65 & $>0.1$ & 4.01 & $<0.05$ & 3.36 & $<0.05$ \\
\hline & \multicolumn{2}{|c|}{$C>B$} & \multicolumn{2}{|c|}{$C=B$} & \multicolumn{2}{|c|}{$\mathrm{C}>\mathrm{B}$} & \multicolumn{2}{|c|}{$C>B$} \\
\hline \multicolumn{9}{|l|}{ b. 3 to $4 \mathrm{~d}$ larvae } \\
\hline \multirow[t]{2}{*}{ Friedman's test } & $x^{2}$ & p & $x^{2}$ & $\mathrm{p}$ & $x^{2}$ & $\mathrm{p}$ & $x^{2}$ & $\mathrm{p}$ \\
\hline & 18.75 & $<0.001$ & 24.80 & $<0.001$ & 23.08 & $<0.001$ & 24.05 & $<0.001$ \\
\hline Tukey's test & q & $\mathrm{p}$ & $q$ & $\mathrm{p}$ & $q$ & p & $q$ & $\mathrm{p}$ \\
\hline \multirow[t]{2}{*}{$A / B$} & 4.24 & $<0.025$ & 3.36 & $>0.001$ & 4.26 & $<0.025$ & \multirow{2}{*}{\multicolumn{2}{|c|}{$\begin{array}{c}4.58<0.01 \\
A>B\end{array}$}} \\
\hline & \multicolumn{2}{|c|}{$A>B$} & \multicolumn{2}{|c|}{$A>B$} & \multicolumn{2}{|c|}{$A>B$} & & \\
\hline \multirow[t]{2}{*}{$\mathrm{A} / \mathrm{C}$} & 5.94 & $<0.001$ & 4.85 & $<0.01$ & 6.71 & $<0.001$ & 6.79 & $<0.001$ \\
\hline & & & & $>\mathrm{C}$ & & & & \\
\hline $\mathrm{B} / \mathrm{C}$ & ${ }^{1.69} \mathrm{C}$ & $\begin{array}{l}>0.5 \\
B\end{array}$ & ${ }^{1.51} \mathrm{C}$ & $\begin{aligned} & >0.5 \\
= & B\end{aligned}$ & 2.45 & $\begin{aligned} & >0.2 \\
= & B\end{aligned}$ & 2.21 & $\begin{array}{l}>0.2 \\
B\end{array}$ \\
\hline c. 5 to 6 d larvae & & & & & & & & \\
\hline Friedman's test & $x^{2}$ & p & $x^{2}$ & $p$ & $x^{2}$ & p & $x^{2}$ & $\mathrm{p}$ \\
\hline & 14.93 & $<0.001$ & 21.47 & $<0.001$ & 21.03 & $<0.001$ & 14.53 & $<0.001$ \\
\hline Tukey's test & $q$ & $\mathrm{p}$ & $q$ & $p$ & q & $\mathrm{p}$ & $q$ & p \\
\hline$A / B$ & 5.17 & $<0.001$ & 3.36 & $<0.05$ & 5.68 & $<0.001$ & 4.91 & $<0.005$ \\
\hline & & & & $>B$ & & & & \\
\hline $\mathrm{A} / \mathrm{C}$ & 4.13 & $<0.01$ & 4.39 & $<0.01$ & 5.56 & $<0.001$ & 4.39 & $<0.01$ \\
\hline & & & & $\mathrm{C}$ & & & & \\
\hline$B / C$ & ${ }^{1.03} \mathrm{C}$ & $\begin{array}{l}>0.1 \\
B\end{array}$ & 1.03 & $\begin{aligned} & >0.1 \\
= & B\end{aligned}$ & 0.13 & $\begin{aligned} & >0.1 \\
= & B\end{aligned}$ & 0.52 & $>0.1$ \\
\hline
\end{tabular}


Table 2. Spirobranchus polycerus. Number of experiments in Set 1 showing a positive $(+)$, negative $(-)$ or neutral $(\mathrm{N})$ photoresponse (based on G-statistic tests)

\begin{tabular}{|crrrrr|}
\hline Larval age & \multicolumn{5}{c|}{ Level of irradiance $\left(\times 10^{14} \mathrm{q} \mathrm{cm}^{-2} \mathrm{~s}^{-1}\right)$} \\
& \multicolumn{1}{c}{147} & 360 & 1045 & 2000 & Total \\
\hline 1 to $2 \mathrm{~d}$ & $5+, 0-, 10 \mathrm{~N}$ & $7+, 4-, 4 \mathrm{~N}$ & $2+, 4-, 9 \mathrm{~N}$ & $5+, 3-, 7 \mathrm{~N}$ & $19+, 11-, 30 \mathrm{~N}$ \\
3 to $4 \mathrm{~d}$ & $5+, 0-, 9 \mathrm{~N}$ & $12+, 0-, 3 \mathrm{~N}$ & $12+, 0-, 3 \mathrm{~N}$ & $9+, 0-, 6 \mathrm{~N}$ & $38+, 0-, 21 \mathrm{~N}$ \\
5 to $6 \mathrm{~d}$ & $9+, 0-, 6 \mathrm{~N}$ & $6+, 2-, 7 \mathrm{~N}$ & $10+, 0-, 5 \mathrm{~N}$ & $14+, 0-, 1 \mathrm{~N}$ & $39+, 2-, 19 \mathrm{~N}$ \\
\hline
\end{tabular}

in 12 of the 30 experiments assessed as photoneutral, i.e. as neither photopositive or photonegative. Populations of 1 to $2 \mathrm{~d}$ larvae appear to consist of a mix of photopositive, photoneutral and photonegative subpopulations. There is no evidence in either G-statistic analysis of individual experiments or in Friedman's ANOVA of grouped experiments for a photonegative subpopulation at 3 to $4 \mathrm{~d}$. G-statistic analysis of individual experiments on 5 to $6 \mathrm{~d}$ larvae show 2 cases of a bimodal distribution $\left(\mathrm{A}=\mathrm{C}>\mathrm{B}\right.$ ), one at $147 \times 10^{14} \mathrm{q}$ $\mathrm{cm}^{-2} \mathrm{~s}^{-1}$ and one at $2000 \times 10^{14} \mathrm{q} \mathrm{cm}^{-2} \mathrm{~s}^{-1}$

Strength of the photopositive response: effects of age, duration of exposure and level of irradiance. The strength of the photopositive response varied significantly with larval age (Kruskal-Wallis test; $p<0.025$; Table 3). All 3 age groups differ from one another in this respect (Tukey's test; $p<0.001$; Table 3). The photopositive response was strongest at 3 to $4 \mathrm{~d}$, weakest at 5 to $6 \mathrm{~d}$.

Duration of exposure $(5,10$ and $15 \mathrm{~min}$ ) had a significant effect on the strength of the photopositive response of 5 to $6 \mathrm{~d}$ larvae $(\mathrm{p}<0.001$; Table 4$)$ and a marginally significant effect on 3 to 4 d larvae $(p<0.1$; Table 4). The response was strongest at $15 \mathrm{~min}$ and this value has been used as the count/experiment in all other analyses. Duration of exposure had no significant effect on the strength of the photopositive response of 1 to $2 \mathrm{~d}$ larvae ( $\mathrm{p}>0.1$; Table 4 ).

The effect of level of irradiance on the strength of the photoresponse is less clear. Analysis of variance shows that the level of irradiance has a significant effect in all 3 age classes ( $p<0.001$ in all cases; Table 4). This effect does not, however, fall into any clear pattern. At 1 to $2 \mathrm{~d}$ the strength of the photopositive response was maximal at 360 and minimal at $1045 \times 10^{14} \mathrm{q} \mathrm{cm}^{-2} \mathrm{~s}^{-1}$. At 3 to $4 \mathrm{~d}$ the maximal response occurred at 360 and the minimal at $147 \times 10^{14} \mathrm{q} \mathrm{cm}^{-2} \mathrm{~s}^{-1}$, and at 5 to $6 \mathrm{~d}$ the situation was reversed with a maximal response at 147 and a minimal at $360 \times 10^{14} \mathrm{q} \mathrm{cm}^{-2} \mathrm{~s}^{-1}$. When all age classes are considered together the strength of the photopositive response, at the 4 levels of irradiance used, declined in the sequence $147>360>2000>$ $1045 \times 10^{14} \mathrm{q} \mathrm{cm}^{-2} \mathrm{~s}^{-1}$. It appears that the photopositive response is stronger at the lower levels of the range of irradiance used. The strength of the photonegative response was greatest at 1 to $2 \mathrm{~d}$ and least at 3 to $4 \mathrm{~d}$ and does not vary significantly with level of irradiance (G-statistic analysis on mean values at each irradiance level on 1 to 2 and 5 to 6 d larvae; $p>0.1$ ).

\section{Set 2 experiments}

The percent of larvae found at $A$ and at $C$ (the strength of photopositive and photonegative responses) in each of the 135 experiments in Set 2 are shown in Figs. 2 and 3 respectively. The distribution of statistically significant (solid symbols) and non-significant (open symbols) values shows that, at $1045 \times 10^{14} \mathrm{q} \mathrm{cm}^{-2}$ $\mathrm{s}^{-1}$, the results of experiments on 1 to $2 \mathrm{~d}$ larvae were either photoneutral or photonegative with one exception, a significantly photopositive response at $49 \mathrm{~h}$. Thereafter, i.e. from 3 to $14 \mathrm{~d}$, behaviour was either photoneutral or photopositive with 2 exceptions, statistically significant photonegative responses at $190 \mathrm{~h}$ $(8 \mathrm{~d})$ and at $234 \mathrm{~h}(10 \mathrm{~d})$. Data for the older larval stages ( 9 to $14 \mathrm{~d}$ ) is sparse, making it difficult to evaluate the significance of these exceptions.

Set 2 experiments indicate that the photoneutralphotonegative response of larvae 16 to $46 \mathrm{~h}$ old to light at $1045 \times 10^{14} \mathrm{q} \mathrm{cm}^{-2} \mathrm{~s}^{-1}$ changed to photopositivephotoneutral during the 48 to $68 \mathrm{~h}$ interval. The strength of the photonegative response was greatest at 18 to $22 \mathrm{~h}$. Set 1 experiments, which tested larvae at 24 to $31 \mathrm{~h}$, indicate a low frequency photonegative response at irradiance levels of 360,1045 and $2000 \times 10^{14} \mathrm{q} \mathrm{cm}^{-2} \mathrm{~s}^{-1}$, coincident with photoneutral

Table 3. Spirobranchus polycerus. Kruskal-Wallis 1-way ANOVA ( $\mathrm{H}$ and $\mathrm{p}$ values) of the percent of larvae at $\mathrm{A}$ (strength of photopositive response) in Set 1 , followed by Tukey's multiple comparisons ( $q$ and $p$ values) comparing 1 to 2,3 to 4 and 5 to 6 d larvae

\begin{tabular}{|c|c|c|c|c|}
\hline \multicolumn{3}{|c|}{ Kruskal-Wallis test } & \multicolumn{2}{|c|}{ Tukey's test } \\
\hline $\mathrm{H}$ & $\mathrm{p}$ & & $q$ & $\mathrm{p}$ \\
\hline 7.95 & $<0.025$ & $\begin{array}{l}1-2 / 3-4 \\
1-2 / 5-6 \\
3-4 / 5-6\end{array}$ & $\begin{array}{r}50.70 \\
41.10 \\
9.60\end{array}$ & $\begin{array}{l}<0.001 \\
<0.001 \\
<0.001\end{array}$ \\
\hline
\end{tabular}


and photopositive responses. No photonegative response was seen at $147 \times 10^{14} \mathrm{q} \mathrm{cm}^{-2} \mathrm{~s}^{-1}$. (Note that here photonegative behaviour started at $16 \mathrm{~h}$ while in Set 1 experiments it started at $24 \mathrm{~h}$.)

\section{DISCUSSION}

Results suggest that the active response of planktonic larvae of Spirobranchus polycerus to white light is photonegative in the first day of life (16 to $22 \mathrm{~h}$ ), changing during the following day to photopositive. Not all larvae in one culture change at the same time but by $3 \mathrm{~d}(72 \mathrm{~h})$ all actively responding larvae are photopositive. Data for late larval stages are sparse but suggest that this response persists, with possible bouts of photonegativity, until larvae are ready to settle. Hulburt (1962) has shown that, in the Caribbean, microflagellates, used as food by planktonic larvae, are optimally abundant in the upper $20 \mathrm{~m}$, a level consistent with photopositive larval behaviour. The observa- tion that Spirobranchus giganteus and S. polycerus are both photopositive suggests a shared genetic component and/or some common advantage. Possibly the latter is access to food.

Assuming an absence of significant modifying influences, the photonegative response of young larvae should keep them below surface waters for the first day of life. Surface waters on the east coast of Barbados arrive in the North and South Equatorial Currents and sweep around both ends of the island to form a northwesterly drift into the Caribbean (Emery 1972). There is however, no information on the direction of flow of deeper water, making premature any assessment of the ecological significance of the early change in sign in the photoresponse. The apparent trend for 5 to $6 \mathrm{~d}$ larvae to show an occasional photonegative response is interesting in relation to the loss of photoresponse (adoption of photoneutral behaviour) reported for late metatrochophores of both Serpula vermicularis and Spirobranchus giganteus (Young \& Chia 1982, Marsden 1984, 1986). It is during the late metatrochophore

Table 4. Spirobranchus polycerus. Kruskal-Wallis 2-way ANOVA (H and $\mathrm{p}$ values) of the percent of larvae at A (strength of photopositive response). Variables = duration of exposure and level of irradiance, followed by Tukey's multiple comparisons (c and $\mathrm{p}$ values) of 1 to 2,3 to 4 , and 5 to $6 \mathrm{~d}$ larvae

\begin{tabular}{|c|c|c|c|c|c|}
\hline & \multicolumn{2}{|c|}{ Kruskal-Wallis test } & & \multicolumn{2}{|c|}{ Tukey's test } \\
\hline & $\mathrm{H}$ & $\mathrm{p}$ & & q & $\mathrm{p}$ \\
\hline \multicolumn{6}{|l|}{1 to $2 \mathrm{~d}$} \\
\hline Duration & $<1$ & $>0.1$ & & & \\
\hline \multirow[t]{5}{*}{ Irradiance } & 7.8 & $<0.001$ & $360 / 1045$ & 3.24 & $<0.1$ \\
\hline & & & $360 / 2000$ & 2.59 & $>0.1$ \\
\hline & & & $147 / 1045$ & 2.20 & $>0.1$ \\
\hline & & & $147 / 2000$ & 1.55 & $>0.1$ \\
\hline & & & $360 / 147$ & 1.04 & $>0.1$ \\
\hline Duration $\times$ Irradiance & $<1$ & $>0.1$ & & & \\
\hline \multicolumn{6}{|l|}{3 to $4 \mathrm{~d}$} \\
\hline Duration & $<1$ & $<0.1$ & & & \\
\hline \multirow[t]{6}{*}{ Irradiance } & 22.21 & $<0.001$ & $147 / 2000$ & 43.77 & $<0.001$ \\
\hline & & & $1045 / 2000$ & 37.2 & $<0.001$ \\
\hline & & & $147 / 360$ & 37.7 & $<0.001$ \\
\hline & & & $360 / 1045$ & 31.1 & $<0.001$ \\
\hline & & & $147 / 1045$ & 6.6 & $<0.001$ \\
\hline & & & $360 / 2000$ & 6.0 & $<0.001$ \\
\hline Duration $\times$ Irradiance & 111696.4 & $<0001$ & & & \\
\hline \multicolumn{6}{|l|}{5 to $6 \mathrm{~d}$} \\
\hline \multirow[t]{3}{*}{ Duration } & 28.43 & $<0.001$ & $5 / 10$ & 11.75 & $<0.001$ \\
\hline & & & $5 / 15$ & 9.52 & $<0.001$ \\
\hline & & & $10 / 15$ & 2.23 & $>0.1$ \\
\hline \multirow[t]{6}{*}{ Irradiance } & 38.56 & $<0.001$ & $147 / 2000$ & 27.76 & $<0.001$ \\
\hline & & & $147 / 360$ & 17.32 & $<0.001$ \\
\hline & & & $147 / 1045$ & 16.86 & $<0.001$ \\
\hline & & & $1045 / 2000$ & 7.90 & $<0.001$ \\
\hline & & & $360 / 2000$ & 7.44 & $<0.001$ \\
\hline & & & $1045 / 360$ & 0.46 & $>0.1$ \\
\hline Duration $\times$ Irradiance & 1581.09 & $<0.001$ & & & \\
\hline
\end{tabular}


Fig. 2. Spirobranchus polycerus. Percent of total number of larvae counted that were found at $A$ (strength of photopositive response) (• ) in Set 2 experiments at $1045 \times 10^{14} \mathrm{q} \mathrm{cm}^{-2} \mathrm{~s}^{-1}$ at 18 to $340 \mathrm{~h}$. Horizontal line represents the percent $(33.3 \%)$ expected at A by chance. Solid symbols represent experiments showing a statistically significant photoresponse (positive or negative). Open symbols represent experiments showing a photoneutral response

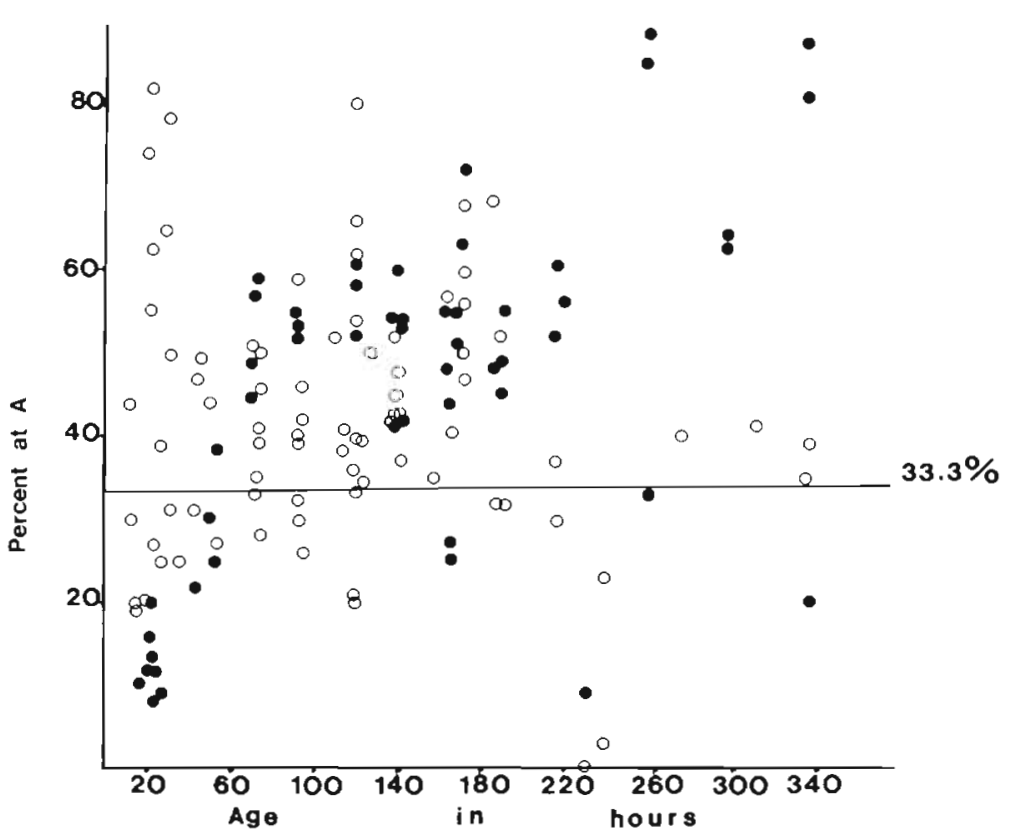

stage that serpulid larvae become demersal, prior to metamorphosis and settlement. This change in behaviour could be related to a loss of the photopositive response.

The photopositive response of 3 to 4 and 5 to $6 \mathrm{~d}$ larvae of Spirobranchus polycerus, like that of other serpulid species studied, is elicited by light in the irradiance range 147 to $2000 \times 10^{14} \mathrm{q} \mathrm{cm}^{-2} \mathrm{~s}^{-1}$. S. polycerus differs from $S$. giganteus in that there were statistically significant differences in the strength of the photopositive response at the 4 different levels of irradiance used. The only indication of a trend, how- ever, is a maximal response to one of the 2 lower levels of irradiance. A stronger response in the lower portion of the range of illumination encountered could reduce the degree of vertical dispersion of larvae.

Although the behaviour of metatrochal Spirobranchus polycerus larvae is statistically photopositive, photoneutral behaviour is not uncommon. In this respect $S$. polycerus differs again from $S$. giganteus. $S$. giganteus larvae, 1 to $4 \mathrm{~d}$ old, were photopositive in $100 \%$ of experiments; $S$. polycerus, 3 to $4 \mathrm{~d}$ old, were photopositive in $44 \%$ of experiments. In addition, the photopositive response of S. giganteus was stronger 65
Fig. 3. Spirobranchus polycerus. Percent of total number of larvae counted that were found at $C$ (strength of photonegative response) (4. 4 ) in Set 2 experiments at $1045 \times 10^{14} \mathrm{q} \mathrm{cm}^{-2} \mathrm{~s}^{-1}$ at 18 to $340 \mathrm{~h}$. Horizontal line represents the percent $(33.3 \%)$ expected at $C$ by chance. Solid symbols represent experiments showing a statistically significant photoresponse (positive or negative). Open symbols represent experiments showing a photoneutral response

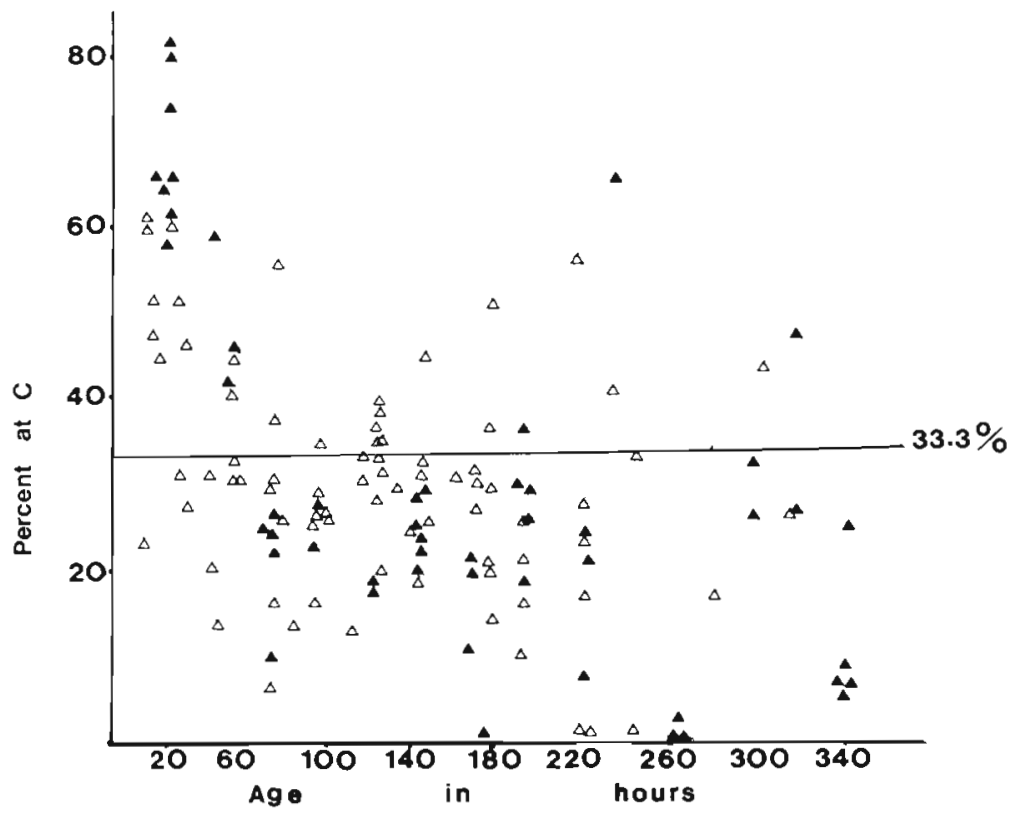


to $95 \%$ at A) than that of S. polycerus ( 44 to $76 \%$ at A). These differences suggest that at 3 to $4 \mathrm{~d}$ the proportion of larvae responding to light is less in a $S$. polycerus population than it is in a $S$. giganteus population. Possibly the observed photoresponse of $S$. polycerus is modified by other, unknown behavioural responses. Movement toward or away from a directional beam of light and a reaction to changing levels of irradiance are only two of several possible responses to light (MacFarland 1986 ), most of them unstudied in relation to planktonic larvae.

The orientation of the eyespot may be important in determining the direction of swimming. It has been shown that the entrance to the microvillus-filled hallow in the pigment cell is directed dorso-posteriorly in photopositive Spirobranchus giganteus larvae and anteriorly in photonegative Serpula vermicularis larvae (Marsden 1984, Marsden \& Hsieh 1987). Larvae of both species swim in a direction that maintains maximal shading of the receptor. The orientation of the eyespot of Spirobranchus polycerus has not been analysed at the ultrastructural level but my own observations of living trochophores and a drawing by Lacalli (1984) both indicate a ventro-posterior orientation with the opening into the hollow directed toward the mouth. There may, therefore, be some difference between $S$. giganteus and $S$. polycerus in the orientation of the body which will maintain maximum shading of the eyespot. If movement toward a source of light is a consequence of maintaining maximal shading then stimulation of the eyespot by light can be expected to result in a change in direction of swimming, e.g. a larva will continue to change direction until it achieves shading of the eyespot. The observed orientation of the eyespot of $S$. polycerus implies that maximum shading will be achieved when the larva is swimming obliquely, not directly, toward a source of light, i.e. larvae may be expected to accumulate and 'mill around' in a broad region at the illuminated end of the chamber rather than in a narrow band close to the window. Such behaviour could help to explain the low frequency and strength of the photopositive response of $S$. polycerus as compared with that of $S$. giganteus

A second possible factor is a difference in rate of adaptation, the weakening of the photoresponse with time. Stimulation of the light-sensitive element of the eyespot when the larva is exploring changes in direction should result in adaptation and eventually a larva may adapt completely and behave in a photoneutral fashion. The speed of adaptation can be expected to be proportional to the intensity of illumination and species are known to differ in their susceptibility to adaptation. One could argue that if Spirobranchus giganteus larvae adapt more slowly than $S$. polycerus larvae then the change from photopositive to photoneutral behaviour will occur earlier in the latter species, resulting in a larger proportion of the population moving in a photoneutral fashion. This effect should be minimal at low levels of irradiance. Two observations made in this study are consistent with this idea: (1) the decline in strength and frequency of the photopositive response of S. polycerus larvae at higher levels of irradiance, and (2) the apparently higher proportion of photoneutral individuals in a $S$. polycerus population than in a $S$. giganteus population.

Although controlled laboratory experiments on larval behaviour can contribute significantly to an understanding of mechanisms of distribution of larvae in the plankton, considered alone, they have limited applicability. To date attempts at determining the distribution of planktotrophic serpulid larvae around Barbados have been unsuccessful and little is known about the movements of relevant coastal waters (Emery 1972). Information of any kind on the distribution or behaviour of polychaete larvae is, however, scarce (Stancyk \& Feller 1986). The 4 studies now available on the photoresponses of planktonic serpulid larvae constitute an information base that could be useful in the design of further experiments and/or in the interpretation of data on distribution in the sea. At present these studies show that planktotrophic serpulid larvae are top-heavy and negatively buoyant (Marsden \& Hassessian 1986) and must be able to swim upward in the water column. They also indicate that all 4 species studied are photoresponsive. In addition, the observations that there are species-specific differences in the orientation of the eyespot, in the sign and strength of the larval photoresponse and in the stage of development at which changes in sign take place, are consistent with natural selection for both morphology and behaviour by environmental parameters of the plankton. Whether or not these differences resuit in a difference in distribution in the sea remains to be seen.

Acknowledgements. This work was supported by a National Science and Engineering Research Council of Canada Operating Grant to J. R. Marsden.

\section{LITERATURE CITED}

Banse, K. (1986). Vertical distribution and horizontal transport of planktunic larvae of echinoderms and benthic polychaetes in an open coastal sea. Bull mar. Sci. 39: 162-175

Bousfield, E. L. (1955). Ecological control of occurrence of barnacles in the Mirimashi estuary. Bull. natn. Mus. Can. 137: $1-69$

Carriker, M. R. (1947). A brief critical survey of the evidence for the horizontal movement of oyster larvae. Proc. natl Shellfish. Ass. (1946): 28-32

Cronin, T W., Forward, R. B. Jr (1986). Vertical migration cycles of crab larvae and their role in larval dispersal. Buil. mar Sci. 39: 192-201 
de Wolf, P. (1973). Ecological observations on the mechanism of dispersal of barnacle larvae during planktonic life and settling. Neth. J. Sea Res. 6: 1-129

de Wolf, P. (1974). On the retention of marine larvae in estuaries. Thalassia jugosl. 10: 415-424

Emery, A. R. (1972). Eddy formation from an oceanic island: ecological effects. Caribb. J. Sci. 12: 121-128

Grosberg, R. K. (1982). Intertidal zonation of barnacles: the influence of planktonic zonation of larvae on the vertical distribution of adults. Ecology 63: 894-899

Hulburt, E. M. (1962). Phytoplankton in the southwestern Sargasso Sea and North Equatorial Current, Feb. 1961. Limnol. Oceanogr. 7: 307-315

Jackson, G. A. (1986). Interaction of physical and biological processes in the settlement of planktonic larvae. Bull. mar. Sci. 39: 202-212

Kunkle, D. E. (1957). The vertical distribution of oyster larvae in Delaware Bay. Proc. natl Shellfish. Ass. 48: 90-91

Lacalli, T. C. (1984). Structure and organization of the nervous system in the trochophore larva of Spirobranchus. Phil. Trans. R. Soc. B 306: 79-135

Levin, L. A. (1986). The influence of tides on larval availability in shallow waters overlying a mudflat. Bull. mar. Sci. 39: $224-233$

Lyster, I. J. H. (1965). The salinity tolerance of polychaetes. J. Anim. Ecol. 34: 517-527

MacFarland, W. N. (1986). Light in the sea -- correlations with behaviour of fishes and invertebrates. Am. Zool. 26 : $389-40.1$

Mackas, D. L., Denman, K. L., Abbott, M. R. (1985). Plankton patchiness; biology in the physical vernacular. Bull. mar. Sci. 37: 652-674

Marsden, J. R. (1984). Swimming in response to light by larvae. of the tropical serpulid Spirobranchus giganteus. Mar. Biol. 83: 13-16

Marsden, J. R. (1986). Response to light by trochophore larvae

This article was submitted to the editor of Spirobranchus giganteus. Effects of level of irradiance, dark adaptation and spectral distribution. Mar Biol. 93: 13-16

Marsden, J. R. (1988). Light responses of the larvae of the serpulid polychaete Galeolaria caespitosa. Mar. Biol. 99: 397-407

Marsden, J. R., Hassessian, H. (1986). The effects of $\mathrm{Ca}^{++}$and catecholamines on swimming cilia of the trochophore larva of the polychaete Spirobranchus giganteus. J. exp. biol. Ecol. 95: 245-255

Marsden, J, R., Hseih, J. (1987). Ultrastructure of the eyespot in three polychaete trochophore larvae (Annelida). Zoomorphology 106: 361-368

Nelson, T. C. (1955). Observations on the behaviour and distribution of oyster larvae. Proc natl Shellfish. Ass. 45: 22-28

Richards, W. J., Lindeman, K. C. (1987). Recruitment dynamics of reef fishes: planktonic processes, settlement and demersal ecologies, and fishery analysis. Bull. mar. Sci. 41: 392-410

Stanczyk, S. E., Feller, R. J. (1986). Transport of non-decapod invertebrate larvae in estuaries: an overview. Bull. mar. Sci. 39: 257-268

Wood, L., Hargis, W. J. Jr (1971). Transport of bivalve larvae in a tidal estuary. In: Fourth European Marine Biology Symposium. In: Crisp, D. J. (ed.). Cambridge Univ. Press, Cambridge

Yoshioka, P. M. (1986). Chaos and recruitment in the bryozoan Membranipora membranacea. Biol. Bull. mar biol. Lab., Woods Hole 39: 408-417

Young, C. M., Chia, F.-S. (1982). Ontogeny and phototaxis during larval development of the sedentary polychaete Serpula vermicularis (L.). Biol. Bull. mar, biol. Lab., Woods Hole 162: $457-468$

Zar, J. H. (1984). Biostatistical analysis, 2nd edn. Prentice-Hall Inc., Englewood Cliffs, NJ

Manuscript first received: December 8, 1988

Revised version accepted: September 5, 1989 